\title{
Monoclonal origin of localised orbital amyloidosis detected by molecular analysis
}

Vancouver Hospital and Health Sciences Centre, University of British Columbia, Vancouver, Canada Department of Pathology S Pasternak V A White R D Gascoyne J Rootman

\section{Department of Ophthalmology S Pasternak V A White S R Perry \\ J Rootman}

British Columbia Cancer Agency R D Gascoyne

\section{Royal Alexandra} Hospital, Edmonton, Alberta, Canada R L C Johnson

\section{Correspondence to:} Dr Valerie White, Department of Pathology, Vancouver Hospital and Health Sciences Centre, 910 West 10th Avenue, Vancouver, BC, Canada, V5Z 1 L8.

Accepted for publication 28 June 1996

Sylvia Pasternak, Valerie A White, Randy D Gascoyne, Stephen R Perry, Royce L C Johnson, Jack Rootman

\begin{abstract}
Aims-Primary localised orbital amyloidosis is a rare disease. The purpose of this study was to describe two cases of primary orbital amyloidosis and emphasise the value of molecular analysis of immunoglobulin gene rearrangement in identifying a monoclonal population of cells responsible for the amyloid production. Methods-Charts and biopsy specimens of each case were reviewed. Conventional light microscopy, immunohistochemistry, and polymerase chain reaction (PCR) analysis for immunoglobulin gene rearrangement were performed in both cases. Results-An unusual presentation of localised primary amyloidosis with bilateral and extensive enlargement of multiple extraocular muscles was seen in case 1 . The presence of amyloid deposits was confirmed by biopsy in both cases. Evidence of a monoclonal population of plasma cells was shown by immunohistochemical analysis in case 2 only. The monoclonal origin of the cells responsible for the amyloid deposition was determined by PCR analysis demonstrating immunoglobulin heavy chain gene rearrangement in both cases.

Conclusions-A monoclonal population of plasma cells responsible for the amyloid deposition was present in these two cases. PCR analysis is extremely helpful in determining monoclonality, a finding that may have important therapeutic and prognostic implications.
\end{abstract}

(Br F Ophthalmol 1996;80:1013-1017)

Amyloidosis comprises a variety of different disease processes, systemic or localised, in which extracellular deposition of abnormal protein fibrils occurs. Localised orbital amyloidosis, where the amyloid deposition is confined to the orbit, in the absence of systemic disease, is rare. There are 23 cases reported of which five are bilateral. ${ }^{1-9}$

We reviewed the literature and describe two new cases of localised orbital amyloid, one of which was bilateral. Both were confirmed by biopsy and evaluated using conventional light microscopy, immunohistochemistry, and polymerase chain reaction (PCR) analysis for immunoglobulin heavy chain gene rearrangement. The latter was used to determine if a monoclonal population of plasma cells was present, indicating the presence of a neoplastic plasma cell disorder responsible for the amyloid deposition.
Materials and methods

Charts were reviewed for details of the patients' presentation and history. Haematoxylin and eosin stained slides were obtained from formalin fixed paraffin embedded tissue samples. Sections from the paraffin blocks were also examined immunohistochemically by the streptavidin-biotin peroxidase technique using commercially available polyclonal antibodies to the following antigens: IgG (1:10 000; Dako, Glostrup, Denmark), IgA (1:1000; Dako), IgM (1:2000; Dako), kappa light chains (1:4000; Dako), lambda light chains (1:8000; Dako).

For PCR analysis of case 1, DNA was extracted from fresh frozen material on an automated DNA extractor (Applied Biosystems, model 341, Foster City, CA, USA). For case 2, DNA was extracted from paraffin embedded tissue sections using proteinase $\mathrm{K}$ in buffer following deparaffinisation in xylene and rehydration in graded alcohols. DNA $0.5 \mu \mathrm{g}$ from case 1 and $10 \mu$ diluted DNA from case 2 were used in a $50 \mu \mathrm{l}$ PCR reaction mixture. A consensus PCR strategy was employed using V region and $J$ region primers for the Ig heavy chain locus. Thirty five rounds of amplification were used and the PCR products visualised on an $8 \%$ polyacrylamide gel. The sizes of the monoclonal bands were compared with the 123 base pair marker. Clonal VDJ IgH rearrangements appear as tight bands ranging in size from 70 to 140 base pairs. ${ }^{10}$ The specimens were analysed with a monoclonal B cell leukaemia/lymphoma KM3 cell line (positive control) and a polyclonal reactive lymph node (negative control).

\section{Results}

CASE 1

A 44-year-old white woman developed typical symptoms of hyperthyroidism when aged 33 She was found to have elevated thyroid hormone levels and was treated with radioactive iodine. Within 1 year of radioactive iodine therapy, she presented with bilateral ocular irritation and protruding eyes. Over the next 7 years the proptosis gradually increased from an initial Hertel measurement of $21 \mathrm{~mm}$ to 28 $\mathrm{mm}$ bilaterally. She underwent bilateral orbital decompression by a medial approach, achieving only $3 \mathrm{~mm}$ recession on the right and $5 \mathrm{~mm}$ on the left. Her soft tissue changes progressed and she underwent bilateral mullerectomies, blepharoplasties, and right dacryocystorhinostomy for epiphora following the decompression. 


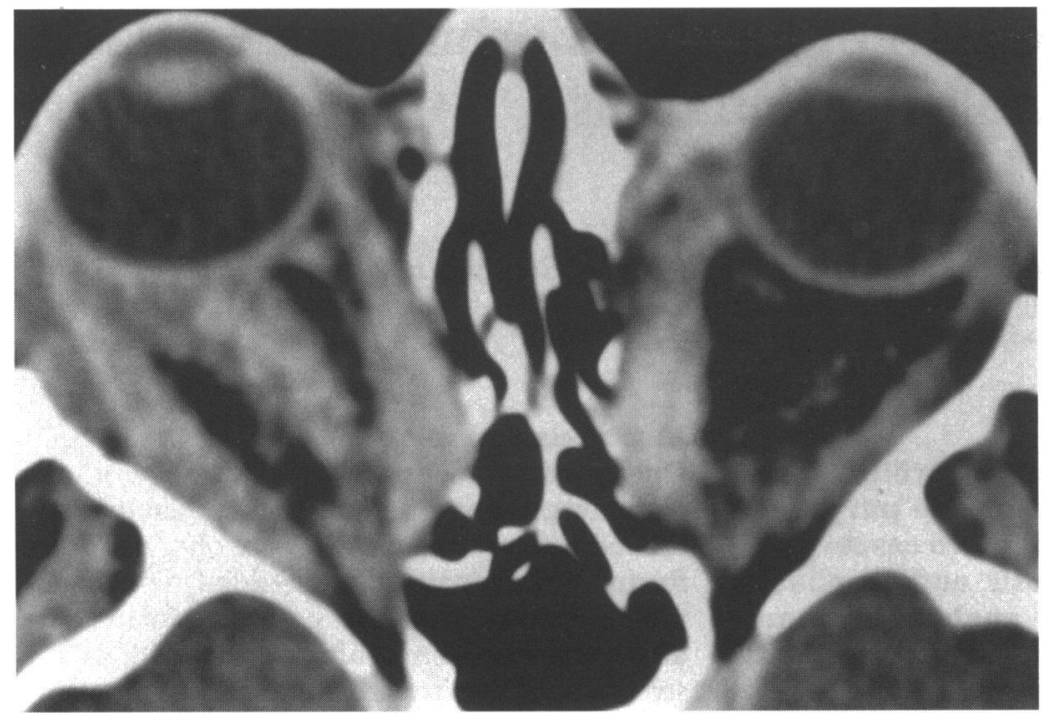

Figure 1. Case 1. Axial computed tomography showing bilateral enlargement of the extraocular muscles, more prominent in the right orbit. The extraocular muscles are thickened and irregular; the muscle tendons are also involved.

She was referred to the University of British Columbia Orbit Clinic for second opinion 9 years into her orbital disease. Review of her previous computed tomography (CT) scans showed progressive deviation from the usual pattern of thyroid orbitopathy. The muscles were very irregularly shaped and enlarged, and both the orbital fat and tendons were also involved (Fig 1).

On ophthalmic examination her visual acuity was $20 / 25$ bilaterally. Both upper lids showed some brawny induration and the right lacrimal gland was palpable. The conjunctiva was minimally injected on the right. There was downward displacement of the right globe by 2 $\mathrm{mm}$ and bilateral exophthalmos with Hertel measurements of $25 \mathrm{~mm}$ on the right and 23 $\mathrm{mm}$ on the left. A mild right lateral rectus underaction was present. The intraocular pressure was $15 \mathrm{~mm} \mathrm{Hg}$ in primary position but elevated to $25 \mathrm{~mm} \mathrm{Hg}$ on upgaze bilaterally. Fundus examination was unremarkable. Full clinical examination, blood tests, bone marrow biopsy, and CT scan of the thorax and abdomen were normal.

Orbital biopsy was suggested because a lymphoproliferative disorder or a sclerosing lesion were considered as possible diagnoses.

Biopsy of the orbital mass and right lateral rectus muscle showed extensive amorphous eosinophilic material that stained positively with Congo red and showed apple green birefringence under polarised light (Fig 2A). Numerous blood vessels were surrounded by collections of plasma cells, admixed with occasional lymphocytes (Fig 2B). Immunoperoxidase stains for immunoglobulin heavy and light chains did not show preferential staining. However, material submitted for PCR analysis showed a monoclonal rearrangement of the immunoglobulin heavy chain gene as evidenced by a band in the appropriate size range (Fig 3). This finding indicated the presence of a monoclonal population of plasma cells, presumably responsible for the amyloid production, and consistent with primary (AL type) amyloidosis.
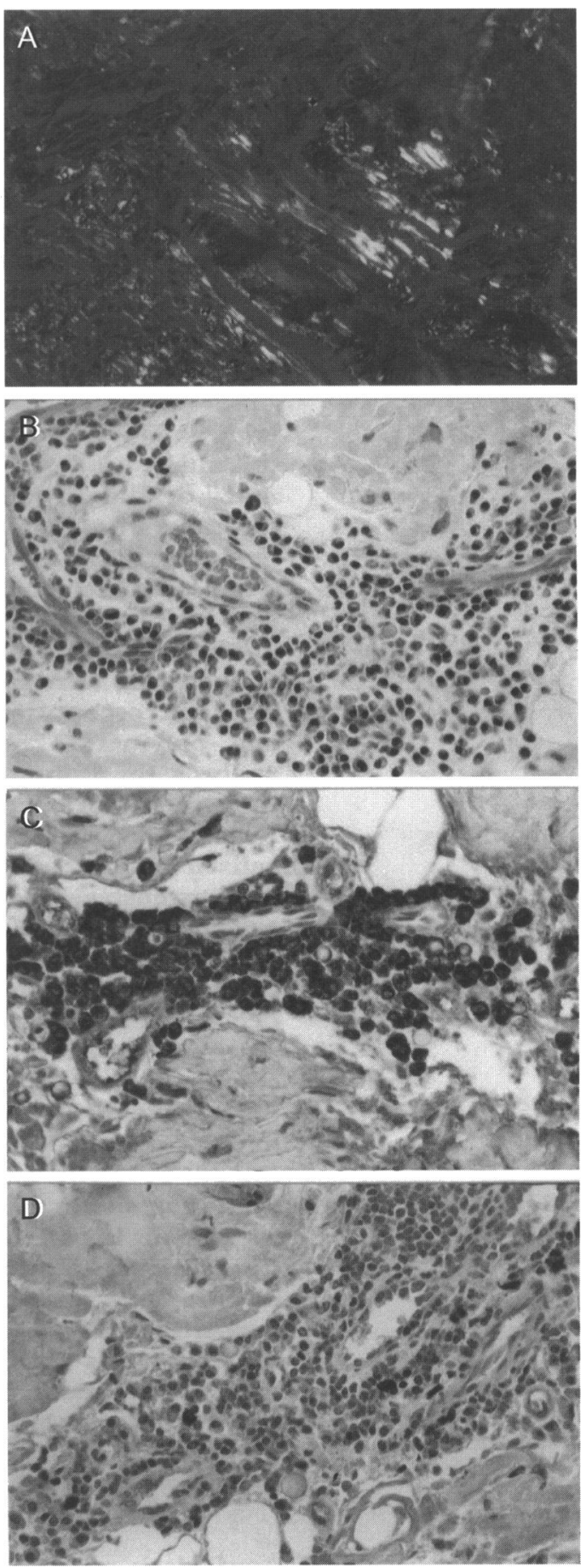

Figure 2 (A) Case 1. Apple green birefringence under polarised light after staining with Congo red, confirming the amyloid nature of the deposits $(\times 400)$. (B) Case 1. High power photomicrograph showing collections of plasma cells around the blood vessels (haematoxylin and eosin; $\times 400$ ). (C) Case 2. Staining of the majority of the cells with antikappa antibody (haematoxylin counterstain, $\times 400$ ).

(D) Case 2. Staining of few cells with anti-lambda antibody (haematoxylin counterstain, $\times 400$ ).

The patient was treated with radiotherapy (3000 cGy) to the right orbit, which was the side most affected. The proptosis regressed and no recurrence has developed after a follow up of 22 months. A discrete mass developed in the left orbit 18 months after the first biopsy. This was biopsied and showed similar histology. The left orbit was also treated with radiotherapy and there has been no recurrence after 3 months. 


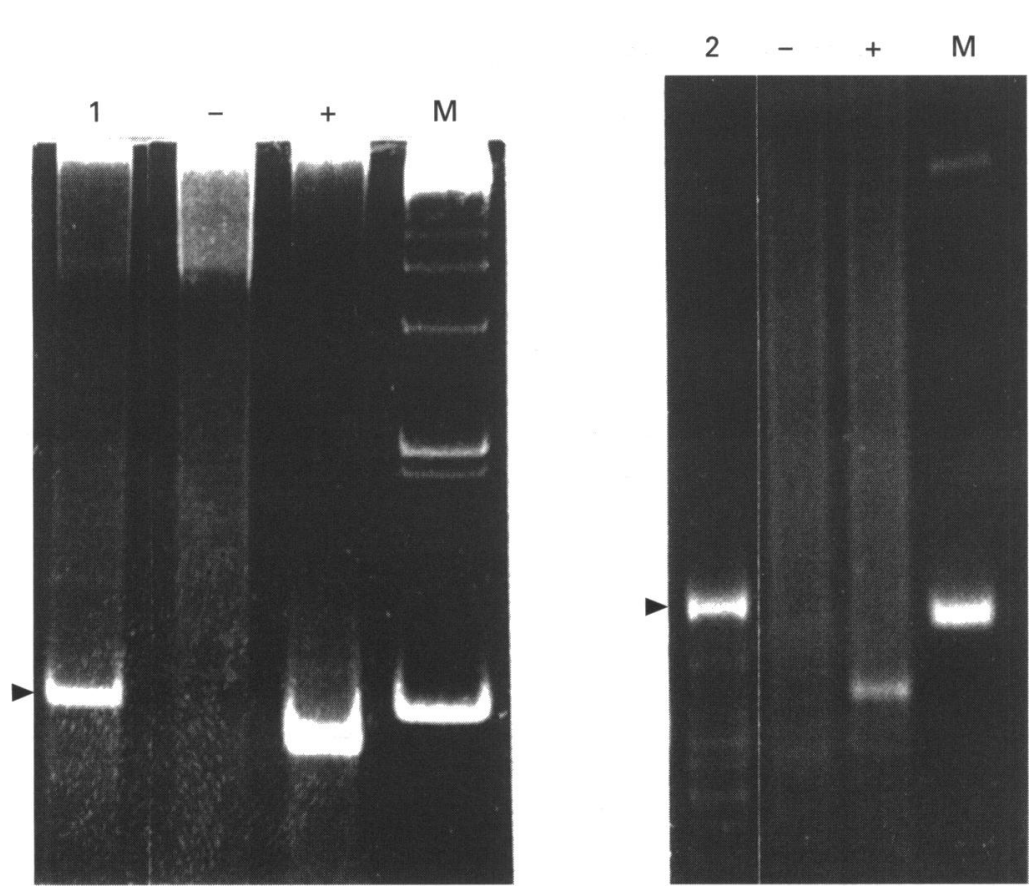

Figure 3 Polymerase chain reaction (PCR) analysis for immunoglobulin heavy chain gene rearrangement. Left, case 1 ; right case $2 .-=$ Negative control, $+=$ positive control, $M$ $=123$ base pair size marker. The rearranged bands are indicated by arrowheads and are within the expected size range of 70-140 base pairs.

\section{CASE 2}

A 60-year-old white man had a 5 year history of a slowly growing mass in his left lower eyelid with ocular irritation. He was in good general health and had no past history of any medical or ocular diseases.

His uncorrected visual acuity was $20 / 20$ on the right and $20 / 30$ on the left. External examination revealed $1 \mathrm{~mm}$ of left proptosis with approximately $1 \mathrm{~mm}$ of elevation of the left globe. There was marked fullness in the left inferior orbit palpable through the lower eyelid. Fundus examination was unremarkable.

Full clinical examination, blood tests, a bone marrow biopsy, and CT scan of the thorax and abdomen failed to reveal any other pathology.

CT scan of the orbit showed an irregular infiltrative inferolateral lesion in the anterior left orbit. There was thinning of the floor of the orbit and small foci of calcification were seen in relation to the lesion. The roof and the lateral wall were intact and the retrobulbar area was unremarkable.

The orbital biopsy showed the presence of extensive amorphous eosinophilic material that stained and had the birefringent qualities of amyloid. A few patches of plasma cells and lymphocytes were present. Immunoperoxidase stains revealed preferential staining for kappa light chains (Fig 2C and 2D). PCR analysis showed a monoclonal immunoglobulin heavy chain gene rearrangement, confirming a monoclonal population of plasma cells (Fig 3 ).

The patient was treated with radiotherapy (3000 cGy). The left orbital lesion regressed and there is no evidence of recurrence after a follow up of 15 months.

\section{Discussion}

Amyloidosis comprises a variety of different disease processes in which extracellular deposition of abnormal protein fibrils occur. These fibrils are derived from different proteins in different forms of the disease. All amyloid fibrils are arranged in a $\beta$ pleated sheet formation, which produces the characteristic apple green birefringence under polarised light, following staining with Congo red. Recently, precise identification and characterisation of the different types of fibril proteins that constitute amyloid deposits has become possible and amyloidosis can now be classified, not only based on clinicopathological features, but also on the nature of the amyloid protein (Table 1). ${ }^{11-16}$

In the orbit amyloidosis may be localised or part of a systemic disorder. ${ }^{17}{ }^{18}$ Systemic amyloidosis involving the orbit may be primary or associated with multiple myeloma. It usually results from deposition of AL amyloid, which is a protein derived from monoclonal immunoglobulin light chains. ${ }^{16-19}$ An important clinical differential point with respect to the likelihood of systemic disease is involvement of the skin of the eyelids with a waxy yellow subcutaneous deposit, frequently associated with spontaneous haemorrhage, which is almost always related to a systemic process. ${ }^{17}$

Localised amyloidosis may produce a diffuse deposition, or may form nodules or tumoral amyloidosis (so called amyloidomas). ${ }^{20}$ Amyloidomas have been described in many sites including the respiratory tract, ${ }^{21-25}$ genitourinary tract, ${ }^{26} 27$ spleen, ${ }^{28}$ breast, ${ }^{29}$ soft tissues, ${ }^{20}$ brain, ${ }^{3031}$ gastrointestinal tract, ${ }^{32}$ and heart. ${ }^{33}$

Although in most of these cases the specific type of amyloid fibril has not been definitely established, the presence of a lymphocytic and/or plasma cell infiltration, ${ }^{2324262933}$ sug-

Table 1 Clinical amyloidosis syndromes and corresponding amyloid fibril

\begin{tabular}{lll}
\hline Clinical syndrome & Fibril protein & Origin \\
\hline Primary amyloidosis & AL & Monoclonal immunoglobulin light chains \\
Amyloidosis associated with multiple myeloma & AL & Monoclonal immunoglobulin light chains \\
Reactive amyloidosis (secondary amyloidosis) & AA & Serum amyloid A (SAA) = acute phase reactant \\
Familial Mediterranean fever & AA & Serum amyloid A (SAA) = acute phase reactant \\
Familial amyloid polyneuropathy (type I, II) & ATTR & Transthyretin \\
Familial amyloidotic cardiomyopathy & ATTR & Transthyretin \\
Senile systemic amyloidosis & ATTR & Transthyretin \\
Familial amyloid polyneuropathy (type II) (Iowa) & AApoAI & Apolipoprotein AI \\
Familial amyloid polyneuropathy (type IV) (Finnish) & AGel & Gelsolin \\
Hereditary cerebral haemorrhage with amyloidosis (Icelandic) & ACys & Cystatin C \\
Alzheimer's disease & A & Protein \\
Down's syndrome & A & Protein \\
Hereditary cerebral haemorrhage with amyloidosis (Dutch) & A & Protein \\
Dialysis related amyloidosis & 2-microglobulin & 2-microglobulin \\
Amyloidosis associated with medullary carcinoma of the thyroid & Precalcitonin & Precalcitonin \\
\hline
\end{tabular}


Table 2 Reported cases of localised orbital amyloidosis

\begin{tabular}{|c|c|c|c|c|c|c|}
\hline Author & No of cases & Location & Treatment & Follow up & Type of amyloid & $\begin{array}{l}\text { Lymphocytic/plasma cell } \\
\text { infiltration }\end{array}$ \\
\hline Nehen $^{1}$ (1979) & 14 (4 bilateral) & $\begin{array}{l}\text { Orbit (11) } \\
\text { Lacrimal gland (3) }\end{array}$ & Surgical excision & $\begin{array}{l}5 \text { cases: recurrence } \\
2 \text { cases: no recurrence } \\
7 \text { cases: lost to follow up }\end{array}$ & NA & Plasma cells present in 7 cases \\
\hline Cohen $^{2}(1979)$ & 1 & $\begin{array}{l}\text { Inner quadrant of the } \\
\text { right orbit }\end{array}$ & Surgical excision & Recurrence after 2 years & NA & Scattered plasma cells \\
\hline Finlay $^{3}(1980)$ & 1 & Left orbit & Surgical excision & $\begin{array}{l}\text { Recurrence after } 8 \\
\text { months }\end{array}$ & NA & Few plasma cells \\
\hline \multirow[t]{2}{*}{ Lucas $^{4}(1982)$} & 2 & $\begin{array}{l}\text { Right upper orbit ( } 1 \\
\text { case) }\end{array}$ & Surgical excision & $\begin{array}{l}\text { Recurrence after } 1 \\
\text { month }\end{array}$ & $\mathrm{AL}$ & $\begin{array}{l}\text { Lymphocytes and occasional } \\
\text { plasma cells }\end{array}$ \\
\hline & & $\begin{array}{l}\text { Left anterior lower } \\
\text { orbit ( } 1 \text { case) }\end{array}$ & Surgical excision & Recurrence after 2 years & AL & Lymphocytes and plasma cells \\
\hline Levine $^{5}(1986)$ & 1 & Right lacrimal gland & Surgical excision & NA & NA & $\begin{array}{l}\text { Lymphocytes and occasional } \\
\text { plasma cells }\end{array}$ \\
\hline $\begin{array}{l}\text { Holmstrom } \\
\text { (1987) }\end{array}$ & 1 & $\begin{array}{l}\text { Right medial rectus } \\
\text { muscle }\end{array}$ & Strabismus surgery & NA & NA & No information \\
\hline Erie $^{7}$ (1989) & 1 & $\begin{array}{l}\text { Right horizontal rectus } \\
\text { muscle }\end{array}$ & Strabismus surgery & Stable after 26 months & NA & No information \\
\hline $\begin{array}{l}\text { Conlon }^{8}(1991) \\
\operatorname{Tan}^{9}(1994)\end{array}$ & $\begin{array}{l}1 \text { (bilateral) } \\
1\end{array}$ & $\begin{array}{l}\text { Lacrimal gland } \\
\text { Upper outer quadrant } \\
\text { of right orbit }\end{array}$ & $\begin{array}{l}\text { No information } \\
\text { No information }\end{array}$ & $\begin{array}{l}\text { NA } \\
\text { NA }\end{array}$ & $\begin{array}{l}\mathrm{AL} \\
\mathrm{AH}\end{array}$ & $\begin{array}{l}\text { Lymphocytes and plasma cells } \\
\text { No information }\end{array}$ \\
\hline
\end{tabular}

$\mathrm{NA}=$ not available.

gests $\mathrm{AL}$ amyloid deposition. In addition, monoclonality could be identified by immunohistochemistry in some cases. ${ }^{22} 232731$ The treatment usually consisted of surgical removal of the amyloid mass and, in the cases where follow up information is available, no systemic diseases developed. ${ }^{21252633}$ However, local recurrences were not uncommon. ${ }^{2122}$

Localised primary orbital amyloidosis is rare. Table 2 outlines the 23 localised orbital amyloidosis cases reported in the literature. Most of the cases involved the anterior orbit. There are five cases involving the lacrimal gland, ${ }^{158}$ one case with amyloidosis isolated to one extraocular muscle, ${ }^{6}$ and one case with amyloid involvement of two extraocular muscles. ${ }^{7}$ Five patients had bilateral orbital involvement. $^{18}$

Many cases of orbital amyloidosis show infiltration of plasma cells suggesting production of immunoglobulins as the basis for the amyloid deposition. ${ }^{1-58}$ However, only in four recent orbital cases was an attempt made to identify the specific type of amyloid fibril involved, by immunohistochemistry, ${ }^{4}$ immunoelectron microscopy, ${ }^{8}$ and extraction and isolation of the amyloid protein. ${ }^{9}$ In these cases amyloid derived from immunoglobulins was encountered, similar to what has been observed in localised amyloidosis elsewhere in the body. ${ }^{2124} 29$ Although immunohistochemical analysis may show evidence of monoclonality in some cases, as in our case 2 , it may fail in others, as in our case 1. PCR analysis definitely established the monoclonal origin of the plasma cells in our two cases. This finding further contributes to the concept of amyloid derived from immunoglobulins as the pathogenic mechanism in localised orbital amyloidosis.

Our case 1 is unique in the fact that there is bilateral orbital amyloidosis with extensive enlargement of multiple extraocular muscles which, to our knowledge, has not been previously reported. The patient's antecedent thyroid disease raised the possibility of AA amyloid (reactive amyloid) deposition secondary to the inflammation related to thyroid orbitopathy. However, if that was the case, a monoclonal population of plasma cells should not be present. In addition, there was no histological evidence of thyroid orbitopathy on the biopsied right lateral rectus muscle.

Some features of localised orbital amyloidosis should be emphasised. Firstly, the amyloid usually extends deeply into the orbit and with an infiltrative pattern, making total surgical excision difficult. Secondly, although no systemic disease developed in the cases where follow up information is available, local recurrences were very frequent. ${ }^{1-4}$ Therefore, therapy aimed at eradicating the neoplastic plasma cells might be considered to arrest the process. We believe that it is reasonable to treat localised amyloidosis with radiotherapy or, perhaps, chemotherapy, if progression is documented and a monoclonal population of cells can be identified.

Both of our patients were treated with radiotherapy. No major side effects occurred but evaluation of the results will require a longer follow up period.

Cases 1 and 2 presented at the Canadian Ophthalmological Society meeting, Victoria, British Columbia, 23-27 June 1995.

None of the authors has proprietary or financial interest in any product or company mentioned in this study.

1 Nehen JH. Primary localized orbital amyloidosis. Acta Ophthalmol 1979;57:287-95.

2 Cohen MM, Lessell S. Amyloid tumor of the orbit. Neuroradiology 1979;18:157-9.

3 Finlay KR, Rootman J, Dimmick J. Optic neuropathy in primary orbital amyloidosis. Can $\dot{\mathcal{f}}$ Ophthalmol 1980;15: 189-92.

4 Lucas DR, Knox F, Davies S. Apparent monoclonal origin of lymphocytes and plasma cells infiltrating ocular adnexal amyloid deposits: report of 2 cases. $\mathrm{Br} \mathcal{F}$ Ophthalmol 1982; 66:600-6.

5 Levine M, Buckman G. Primary localized orbital amyloidosis. Ann Ophthalmol 1986;18:165-7

6 Holmstrom GE, Nyman KG. Primary orbital amyloidosis localised to an extraocular muscle. $\mathrm{Br} f$ Ophthalmol 1987;71:32-3.

7 Erie JC, Garrity JA, Norman ME, Minn R. Orbital amyloidosis involving the extraocular muscles. [Letter] Arch Ophthalmol 1989;107:1428-9.

8 Conlon MR, Chapman WB, Burt L, Larocque BJ, Hearn SA. Primary localized amyloidosis of the lacrimal glands. Ophthalmology 1991;98:1556-9.

9 Tan SY, Murdoch IE, Sullivan TJ, Wright JE, Truong O, Hsuan JJ, et al. Primary localized orbital amyloidosis composed of the immunoglobulin $\mathrm{g}$ heavy chain $\mathrm{CH} 3$ domain Clin Sci 1994;87:487-91.

10 Greiner TC, Gascoyne RD, Anderson ME, Kingma DW, Adomat SA, Said J, et al. Nodular lymphocyte predominant Hodgkin's disease associated with large cell lymphoma: analysis of Ig gene rearrangements by VJ polymerase chain reaction. Blood 1996;80:657-66. 
11 Glenner GG. Amyloid deposits and amyloidosis-the betafibrilloses I. N Engl f Med 1980;302:1283-92.

12 Glenner GG. Amyloid deposits and amyloidosis-the betafibrilloses II. N Engl ₹ Med 1980;302:1333-43.

13 Tan SY, Pepys MB. Amyloidosis. Histopathology 1994;25: 403-14.

14 Cohen AS, Connors LH. The pathogenesis and biochemistry of amyloidosis. $\mathcal{F}$ Pathol 1987;151:1-10.

15 Husby G, Sletten K. Chemical and clinical classification of amyloidosis. Scand $\mathcal{f}$ Immunol 1986;23:253-65.

16 Klintworth GK. Proteins in ocular disease. In: Garner A Klintworth GK, eds. Pathobiology of ocular disease. New Klintworth GK, eds. Pathobiology of

17 Jakobiec FA, Font RL. Amyloid. In: Spencer WH, ed. Oph thalmic pathology: an atlas and textbook. Philadelphia: WB Saunders, 1986:2807-12.

18 Sandgren O. Ocular amyloidosis, with special reference to the hereditary forms with vitreous involvement. Surv Ophthalmol 1995;40:173-96.

19 Knowles DM, Jakobiec FA, Rosen M, Howard G. Amyloidosis of the orbit and adnexae. Surv Ophthalmol 1975;19;367-84.

20 Krishnan J, Chu W, Elrod JP, Frizzera G. Tumoral presentation of amyloidosis (amyloidomas) in soft tissues. Am $\mathcal{f}$ Clin tion of amyloidosis (1993;100:135-44.

21 Costa P, Corrin B. Amyloidosis localized to the lower respiratory tract: propable immunoamyloid nature of the tracheobronchial and nodular pulmonary forms. Histopathology 1985;9:703-10.

22 Lewis JE, Olsen KD, Kurtin PJ, Kyle RA. Laryngeal amyloidosis: a clinicopathologic and immunohistochemical review. Otolaryngol Head Neck Surg 1992;106:372-7.

23 Berg AM, Troxler RF, Grillone G, Kasznica J, Kane K, Cohen AS, et al Localized amyloidosis of the larynx: evidence for light chain composition. Ann Otol Rhinol Laryngol 1993;102:884-9.
24 Toyoda M, Ebihara Y, Kato H, Kita S. Tracheobronchial AL amyloidosis: histologic, immunohistochemical, ultrastructural and immunoelectron microscopic observations. Hum Pathol 1993;24:970-6.

25 Mollers MJ, van Schaik JPJ, van der Putte SCJ. Pulmonary amyloidoma. Histologic proof yielded by transthoracic coaxial fine needle biopsy. Chest 1992;102:1597-8.

26 Khan SM, Birch PJ, Bass PS, Williams JH, Theaker JM. Localized amyloidosis of the lower genitourinary tract: a clinicopathological and immunohistochemical study of nine cases. Histopathology 1992;21:143-7.

27 Ehara $H$, Deguchi T, Yanagihara $M$, Yokota $T$, Uchino $F$ Kawada Y. Primary localized amyloidosis of the bladder: an immunohistochemical study of a case. $\mathcal{F}$ Urol 1992;147: 458-60.

28 Chen KTK, Flam MS, Workman RD. Amyloid tumor of the spleen. Am f Surg Pathol 1987;11:723-5.

29 Silverman JF, Dabbs DJ, Norris HT, Pories WJ, Legier J, Kay S. Localized primary (AL) amyloid tumor of the breast. Cytologic, histologic, immunocytochemical and ultrastructural observations. Am f Surg Pathol 1986;10: 539-45.

30 Cohen M, Lanska D, Roessmann U, Karaman B, Ganz E Whitehouse P, et al. Amyloidoma of the CNS. I. Clinical and pathologic study. Neurology 1992;42:2019-23.

31 Vidal RG, Ghiso J, Gallo G, Cohen M, Gambetti PL, Frangione B. Amyloidoma of the CNS. II. Immunohistochemical and biochemical study. Neurology 1992;42:2024-28.

32 Jensen K, Raynor S, Rose SG, Bailey ST, Schenken JR Amyloid tumors of the gastrointestinal tract: a report of two cases and review of the literature. Am $\mathcal{f}$ Gastroenterol 1985; 80:784-6.

33 Warner KJ, Blackwell GG, Herrera G, Listinsky C, Holman WL, Rustagi PK. Cardiac amyloidoma with IgM-K gammopathy. Arch Pathol Lab Med 1994;118:114850. 